\title{
Preparation of $\mathrm{NO}_{2}$-Aged Silver-Functionalized Silica-Aerogel and Silver Mordenite Samples
}

\section{Fuel Cycle Research \& Development}

\author{
Prepared for \\ US Department of Energy \\ Materials Recovery and Waste Form \\ Development Campaign
}

J. A. Jordan

S. H. Bruffey

September 2016

FCRD-MRWFD-2016-000358

ORNL/TM-2016/546

Approved for public release.

Distribution is unlimited. 



\section{DISCLAIMER}

This information was prepared as an account of work sponsored by an agency of the U.S. Government. Neither the U.S. Government nor any agency thereof, nor any of their employees, makes any warranty, expressed or implied, or assumes any legal liability or responsibility for the accuracy, completeness, or usefulness, of any information, apparatus, product, or process disclosed, or represents that its use would not infringe privately owned rights. References herein to any specific commercial product, process, or senvice by trade name, trade mark, manufacturer, or otherwise, does not necessarily constitute or imply its endorsement, recommendation, or favoring by the U.S. Government or any agency thereof. The views and opinions of authors expressed herein do not necessarily state or reflect those of the U.S. Government or any agency thereof. 



\section{SUMMARY}

Reprocessing used nuclear fuel can result in the volatilization of radioactive gaseous species, including ${ }^{129}$ I, into the various process off-gas streams. In order to comply with US regulatory requirements, plant off-gas streams must be treated to remove the iodine prior to discharging the off-gas into the environment. The performance of available gas removal methods depends not only on the concentration of the volatile radioisotope of interest, but also on other constituents that could be present in the reprocessing off-gas streams. Some of the constituents, such as $\mathrm{NO}_{\mathrm{x}}$ produced during fuel dissolution, are known to have deleterious effects on the capture performance of silver-based sorbents used for iodine removal.

Commercially available reduced silver mordenite (AgZ) has an iodine saturation concentration of 7.0-9.0 wt $\%$, and its iodine sorption capacity is reduced by $20-50 \%$ as a result of $\mathrm{NO}_{2}$ aging. Silver-

functionalized silica aerogel (AgAerogel), an alternative for iodine capture, has an initial iodine saturation of $29.0 \mathrm{wt} \%$ and its iodine capacity is only reduced by $15 \%$ from $\mathrm{NO}_{2}$ aging. Understanding the differences in aging behavior between $\mathrm{AgZ}$ and $\mathrm{AgAerogel}$ is critical to determining the behavior of these sorbents under realistic off-gas conditions. To assist in future technical studies on this topic, samples of both $\mathrm{AgZ}$ and AgAerogel were aged with $\mathrm{NO}_{2}$. In the experiment, $10.2190 \mathrm{~g}$ of AgZ and $10.1771 \mathrm{~g}$ of AgAerogel were exposed to a static $0.75 \% \mathrm{NO}_{2} /$ dry air blend for a period of 28 days. The samples were then removed and stored under argon until needed for future experiments. 
This page intentionally left blank. 


\section{CONTENTS}

SUMMARY

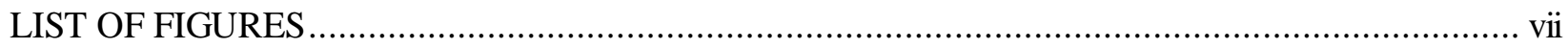

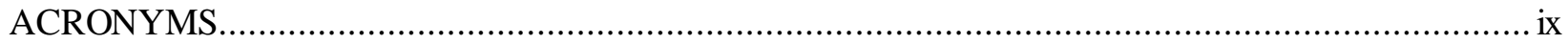

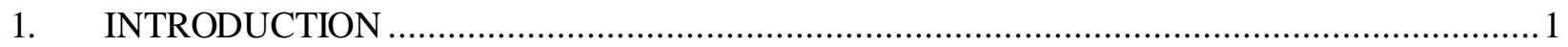

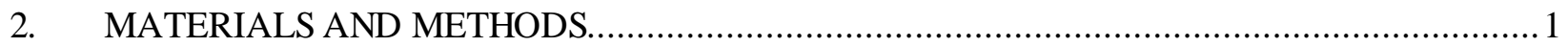

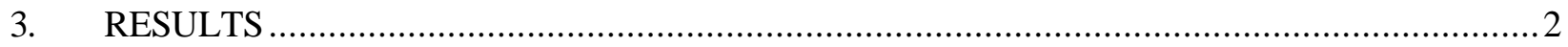

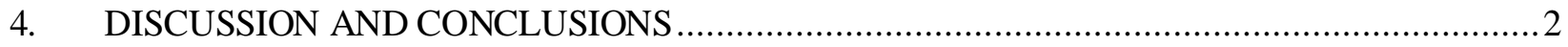

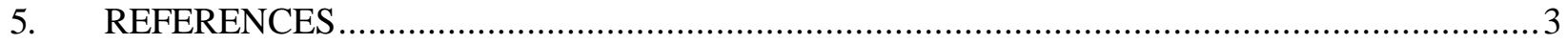


This page intentionally left blank. 


\section{LIST OF FIGURES}

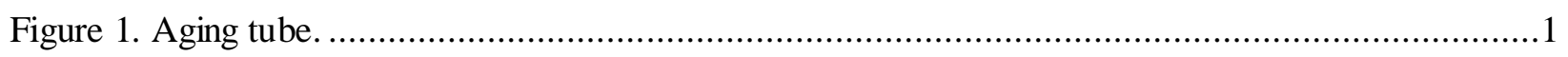

Figure 2. Top, left-to-right: unaged AgAerogel and aged AgAerogel; Bottom, left-to-right: unaged $\mathrm{Ag}^{0} \mathrm{Z}$ and aged $\mathrm{Ag}^{0} \mathrm{Z}$. 
This page left intentionally blank. 


\section{ACRONYMS}

$\begin{array}{ll}\text { AgAerogel } & \text { silver-functionalized aerogel } \\ \mathrm{AgZ} & \text { silver-exchanged mordenite } \\ \mathrm{Ag}^{0} \mathrm{Z} & \text { reduced silver-exchanged mordenite } \\ \mathrm{BET} & \text { Brunauer-Emmett-Teller } \\ \text { EPA } & \text { US Environmental Protection Agency } \\ \text { LPM } & \text { liters per minute } \\ \text { NEUP } & \text { Nuclear Energy University Program } \\ \text { ORNL } & \text { Oak Ridge National Laboratory } \\ \text { PNNL } & \text { Pacific Northwest National Laboratory } \\ \text { SEM } & \text { scanning electron microscopy } \\ \text { UNF } & \text { used nuclear fuel } \\ \text { XRD } & \text { x-ray diffraction }\end{array}$


This page intentionally left blank. 


\section{PREPARATION OF NO $\mathrm{N}_{2}$-AGED AGAEROGEL AND AGZ SAMPLES}

\section{INTRODUCTION}

Reprocessing used nuclear fuel (UNF) can result in the volatilization of several radioactive gaseous species, including ${ }^{3} \mathrm{H},{ }^{14} \mathrm{C},{ }^{85} \mathrm{Kr}$, and ${ }^{129} \mathrm{I}$, into the various process off-gas streams. These off-gas streams require treatment prior to environmental discharge in order to comply with US Environmental Protection Agency (EPA) regulations on the emissions of volatile radioisotopes to the environment. Several silverbased solid sorbent materials are being evaluated for potential use in the treatment of off-gas streams containing iodine (Jubin et al. 2012). The performance of these materials depends not only on the concentrations of the volatile radioisotope of interest, but also on any other gas constituents that could be present in the off-gas streams. Some of the constituents have been shown to adversely impact the capacity of the sorbent materials (Bruffey et al. 2015a; Bruffey et al. 2015b).

It is important to understand the effects of these various constituents in gas capture performance. As oxidizing gases, $\mathrm{NO}$ and $\mathrm{NO}_{2}$ have been shown to have deleterious effects on the iodine capture performance of silver-exchanged mordenite (AgZ) (Bruffey et al., 2015b; Jubin et al. 2013). Commercially available reduced AgZ has an iodine saturation concentration of 7.0-9.0 wt\% AgZ, and aging in a static $2 \% \mathrm{NO}_{2}$ environment for 1-2 months can reduce AgZ's loading capacity by $25-50 \%$ (Jubin, et al. 2013). Silver-functionalized silica-aerogel (AgAerogel) has an iodine saturation concentration of $29.0 \mathrm{wt} \%$, but 2 months of static $2 \% \mathrm{NO}_{2}$ aging was shown to only reduce the loading capacity by $15 \%$ (Bruffey et al. 2015a). The origin of the difference in the performance degradation between these two materials is not currently understood.

The objective of this effort is to prepare samples of $\mathrm{NO}_{\mathrm{x}}$ aged $\mathrm{AgZ}$ and $\mathrm{Ag}$ aerogel that can be utilized at this and other laboratories to aid in gaining insight into the aging mechanism(s).

\section{MATERIALS AND METHODS}

Commercially available silver-exchanged mordenite (AgZ, Ionex-Type Ag 900 E16) was procured from Molecular Products in an engineered pelletized form that contains $9.5 \mathrm{wt} \%$ silver. The binder for the engineered form is a proprietary clay-based material that is added to the crystalline zeolite structure. The silver in this material was reduced through extended exposure at elevated temperature to a $\mathrm{H}_{2} / \mathrm{N}_{2}$ gas blend. Reduced AgAerogel was provided by PNNL in FY 2014. The AgAerogel had a bulk density of $614 \mathrm{~kg} / \mathrm{m}^{3}$ (as measured by ORNL), a surface area of $134 \mathrm{~m}^{2} / \mathrm{g}$, a pore volume of $0.46 \times 10^{-6} \mathrm{~m}^{3} / \mathrm{g}$, an adsorption pore size of $17 \mathrm{~nm}$, and a desorption pore size of $13 \mathrm{~nm}$ (Matyas 2013). Testing of the AgAerogel demonstrated an initial unaged iodine loading capacity of $29.0 \mathrm{wt} \%$ (Bruffey et al. 2015a).

The aging tubes used in this experiment (Figure 1) were assembled from $1 \mathrm{in}$. (outer diameter) 316 stainless steel tubing with a wall thickness of $0.083 \mathrm{in}$., resulting in a cross section of 0.546 in. $^{2}$ (3.52 $\mathrm{cm}^{2}$ ). The overall volume of a single loading chamber was measured to be approximately $90 \mathrm{~cm}^{3}$.

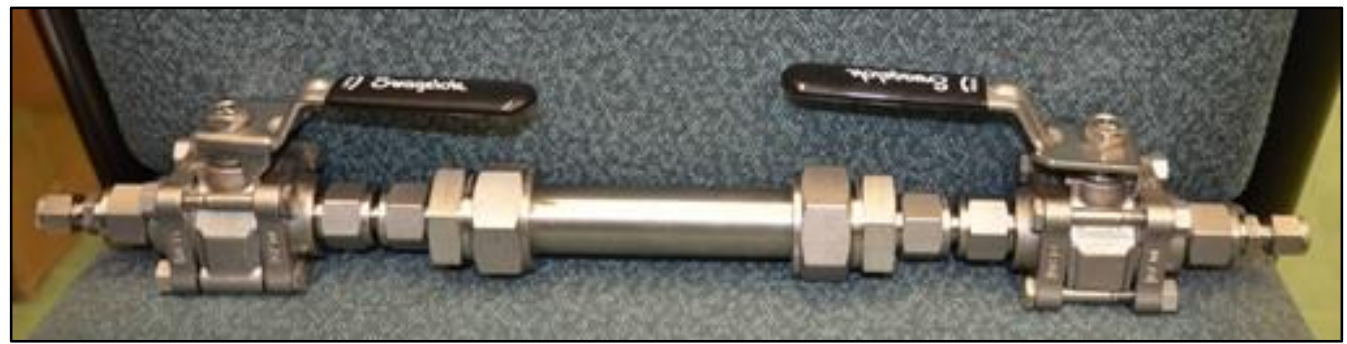

Figure 1. Aging tube. 
Tube 1 contained $10.2190 \mathrm{~g}$ of $\mathrm{AgZ}$ and Tube 2 contained $10.1771 \mathrm{~g}$ of AgAerogel. For each experiment, the sorbents were contained between metal mesh that allowed gas flow through the chamber but did not allow for sorbent movement. A $0.75 \% \mathrm{NO}_{2}$ /bal dry air gas blend (inlet dew point of $-70{ }^{\circ} \mathrm{C}$ ) was passed through the loaded aging tubes for 2.5 minutes each to replace the ambient air environment of the chamber with the $\mathrm{NO}_{2}$ gas blend; this resulted in approximately 65 volume changes (air turnover within the tube). The tubes were then sealed with the $\mathrm{NO}_{2}$ gas blend inside and held at $150{ }^{\circ} \mathrm{C}$ for 28 days. The chambers were then allowed to cool and then purged with dry air for a period of 2.25 hours at 2 liters per minute (LPM). The aged materials were stored in glass sample vials under argon gas.

\section{RESULTS}

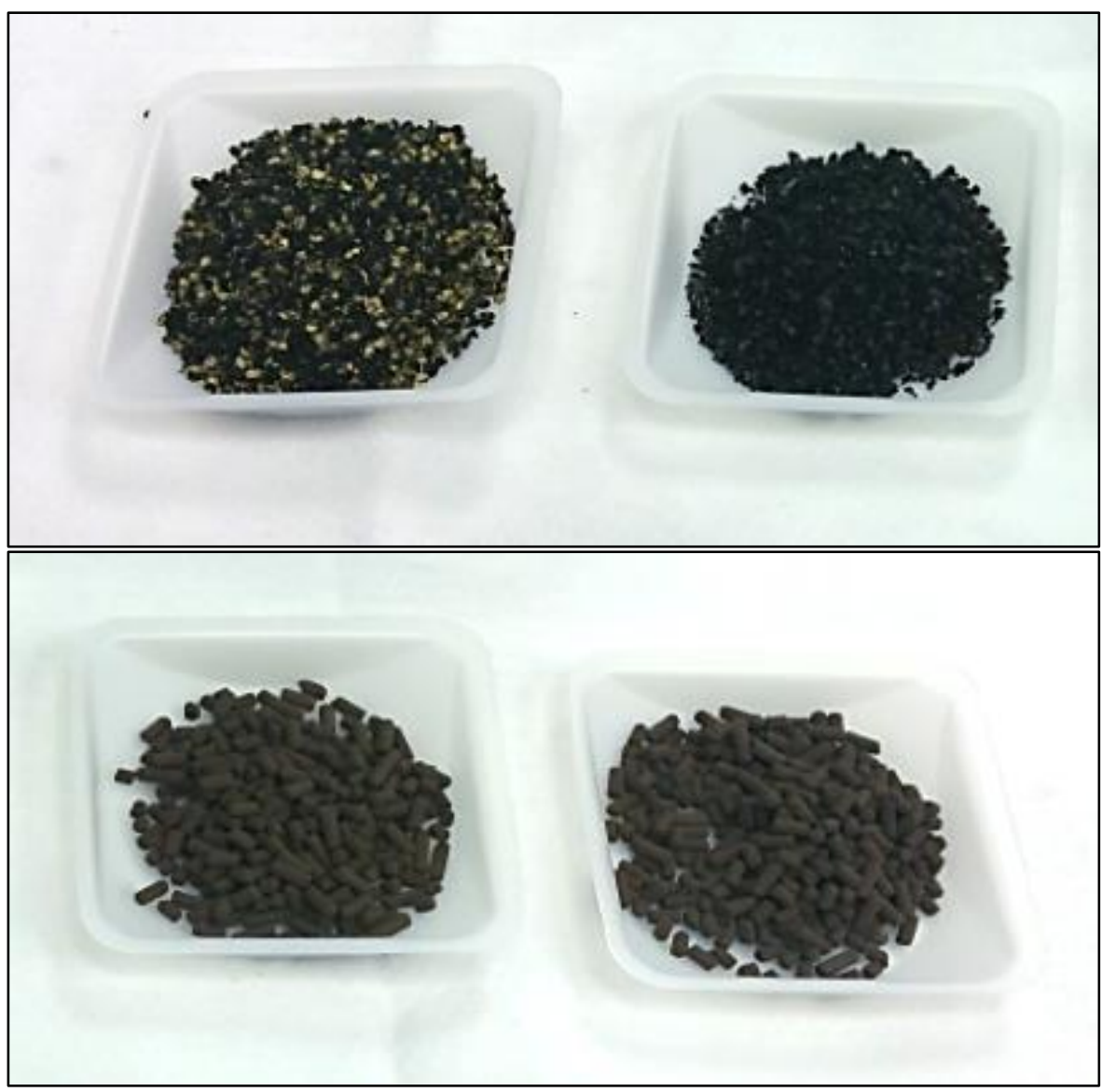

Figure 2. Top, left-to-right: unaged AgAerogel and aged AgAerogel; Bottom, left-to-right: unaged $\mathrm{Ag}^{0} \mathrm{Z}$ and aged $\mathrm{Ag}^{0} \mathrm{Z}$.

The AgAerogel sample underwent observable physical changes upon exposure to the $\mathrm{NO}_{2}$ stream. AgAerogel (the two top images in Figure 2) experienced a color change in some of the material, losing the yellow flecks of color in the original material. The AgZ was visually unchanged through the aging process.

\section{DISCUSSION AND CONCLUSIONS}

Samples of two silver-based iodine sorbents, AgAerogel and $\mathrm{AgZ}$, were exposed to $\mathrm{NO}_{2}$ for approximately 1 month in order to allow future testing of these sorbents (and these samples in particular) for the effect of $\mathrm{NO}_{2}$ aging on iodine capture. The AgAerogel sample underwent a color change in the presence of $\mathrm{NO}_{2}$, while the AgZ remained visually similar to unaged AgZ. The iodine loading capacity of both samples will be determined to confirm that these materials exhibit similar degradation in capacity as 
previously observed. Once these loading tests have been completed, samples of these materials will be available for use at other laboratories upon request. Subsequent evaluations are expected to include surface and structure analysis via scanning electron microscopy (SEM), Brunauer-Emmett-Teller (BET), and x-ray diffraction (XRD) characterization. The samples were prepared at ORNL and will be analyzed by collaborators at Pacific Northwest National Laboratory (PNNL) and various Nuclear Energy University Programs (NEUPs).

\section{REFERENCES}

Bruffey, S. H., K. K. Patton, and R. T. Jubin. 2015a. Complete Iodine Loading of NO-Aged Ag ${ }^{0}$ Functionalized Silica Aerogel. Report No. FCRD-MRWFD-2015-000419, Oak Ridge, TN: UTBattelle, LLC, Oak Ridge National Laboratory.

Bruffey, S. H., K. K. Patton, J. F. Walker Jr., and R. T. Jubin. 2015b. Complete $\mathrm{NO}$ and $\mathrm{NO}_{2}$ Aging Study for AgZ. Report No. FCRD-MRWFD-2015-000631, Oak Ridge, TN: UT-Battelle, LLC, Oak Ridge National Laboratory.

Jubin, R. T., K. K. Anderson, C. V. Bates, S. H. Bruffey, L. Stenzel, B. B. Spencer, and J. F. Walker, Jr. 2013. Complete studies of iodine loading on $N O_{x}$ aged AgZ. Report No. ORNL/LTR-2013/351, Oak Ridge, TN: UT-Battelle, LLC, Oak Ridge National Laboratory.

Jubin, R. T., N. R. Soelberg, D. M. Strachan, and G. Ilas. 2012. Fuel Age Impacts on Gaseous Fission Product Capture during Separations. Report No. FCRD-SWF-2012-000089, Oak Ridge, TN: UT-Battelle, LLC, Oak Ridge National Laboratory.

Matyas, J. 2013. Production of $\mathrm{Ag}^{0}$-functionalized silica aerogel for testing at ORNL. Report No. FCRDTIO-2011-000050, Battelle Memorial Institute, Pacific Northwest National Laboratory. 
This page intentionally left blank. 